Yevchun, H., Dykyi, E., Kozeretska, I., Fedchuk, A.,

Karamushka, V., Parnikoza, I. (2021). Minimizing tourist impact

on the Argentine Islands ecosystem, Antarctic Peninsula,

using visitor site guidelines approach.

Ukrainian Antarctic Journal, 1, 98-116.

https://doi.org/10.33275/1727-7485.1.2021.669

H. Yevchun ${ }^{1,2, *}$, E. Dykyi ${ }^{1}$, I. Kozeretska ${ }^{1}$,

A. Fedchuk ${ }^{1}$, V. Karamushka ${ }^{2}$, I. Parnikoza ${ }^{1,2,3}$

${ }^{1}$ State Institution National Antarctic Scientific Center, Ministry of Education

and Science of Ukraine, Kyiv, 01601, Ukraine

${ }^{2}$ National University of Kyiv-Mohyla Academy, Kyiv, 04655, Ukraine

${ }^{3}$ Institute of Molecular Biology and Genetics, National Academy of Sciences

of Ukraine, Kyiv, 03680, Ukraine

*Corresponding author: hanna.yevchun@gmail.com

\title{
Minimizing tourist impact on the Argentine Islands ecosystem, Antarctic Peninsula, using visitor site guidelines approach
}

\begin{abstract}
There has been an ongoing increase in tourist visits to the Antarctic since 2010. These visits primarily concentrate on a small number of sites, increasing the possible environmental impact. One of the tourism hotspots is the central Argentine Islands in Wilhelm Archipelago. These islands, being one of the top 20 most visited Antarctic sites, consist of Galindez Island, Winter Island, and Skua Island. They are known for wildlife, rich vegetation (old moss banks, rich bryophyte and lichen communities, Antarctic pearlwort Colobanthus quitensis and hairgrass Deschampsia antarctica populations), spectacular views. They include one of the oldest Antarctic research stations: the Ukrainian Antarctic Akademik Vernadsky station. Previously no measures have been developed to minimize the impact of tourism on this region. Thus, the Visitor Site Guidelines (VSG) approach and the numerous studies in the region were used to determine the central values of this site and to identify those key features that can be opened for tourists. In addition to the most frequently mentioned values, such as seabirds and mammals, we considered it necessary to mention the vegetation. We assessed threats to these values, distinguishing known and potential impacts. We have also analyzed and developed landing requirements for the studied area, including the most critical requirement to be considered, namely the number of visitors. We think that the maximum number of visitors should be 36 at any time and 270 per day, not counting passengers of yachts. This is the first time that the Visitor Site Guidelines were modified to limit the number of yachts visiting the site to three yachts per day. To reduce the tourist load at the station itself and at the same time to concentrate tourists in the studied region, we proposed two tourist trails: one for Galindez Island, the other - the existing trail for Winter Island. The prepared draft of Visitor Site Guidelines is given in Appendix 2.
\end{abstract}

Keywords: Galindez Island, Winter Island, Skua Island, Antarctic tourism, environmental impact, Antarctic Treaty

\section{Introduction}

Antarctic landscapes and wilderness attract many visitors from all over the world. According to the International Association of Antarctica Tour Operators (IAATO), tourist numbers doubled in the last five years: 73991 in 2020 compared to 36271 in 2015 (IAATO, 2019; IAATO, 2020). The numbers of landed and crui- se-only passengers have been steadily growing since 2011 (Bender et al., 2016). Antarctic tourism is likely to grow and expand (Bender et al., 2016), requiring accurate regulation to prevent damage to the fragile Antarctic environment on the most visited sites.

A number of studies analyzed the spatial distribution of tourism landings and activities in the Antarctic (Naveen et al., 2001; Bender et al., 2016). Among 
all antarctic territories, the maritime Antarctic ${ }^{1}$ attracts the greatest number of tourists (IAATO, 2020). This region covers the Western Antarctic Peninsula, including South Shetland Islands, South Orkney, and South Sandwich Islands (Riffenburgh, 2006). Biodiversity of this region is the richest in the Antarctic (Hughes et al., 2020; Parnikoza et al., 2018); it includes mosses, lichens, algae, both native vascular Antarctic plants (Ochyra et al., 2008; Parnikoza et al., 2018; Bargagli, 2020), many Antarctic seabirds and most of marine mammals. The layout of this biodiversity often coincides with the most visited tourist sites.

To our knowledge, the latest analyses of tourist visits to the maritime Antarctic cover the periods from 2003 to 2009 (CEP, 2012) and from 1994 to 2013, respectively (Bender et al., 2016). According to the Committee for Environmental Protection (CEP) report (2012), in 2003-2009, the average annual number of visitors to the 20 most visited sites ranged between approximately 2.000 and 14.000 , with five sites receiving over 10.000 passenger landings per season. As for the 2012/2013 season, 24 sites $^{2}$ received at least 2.000 visitors, with two sites receiving more than 16.000 visitors each (Bender et al., 2016). Thus, antarctic tourism activity is unevenly distributed and concentrated mainly in a few dozen locations, putting additional pressure on wildlife.

Article 8 of the Protocol on Environmental Protection to the Antarctic Treaty requires environmental assessment for all activities in the Antarctic Treaty area. However, activities considered less than minor or transitory impact (such as tourism) are not subject to Environmental Impact Assessment process. Thus, there is currently no methodology approved by Antarctic Treaty Consultative Meeting (ATCM) or CEP for assessing risks or impacts on the most visited tourist sites (CEP, 2012). However, there are different studies on visitor impacts on Antarctic wildlife, from general

${ }^{1}$ The expression "the maritime Antarctic" is now widely used to refer to the biodiversity/tourist region. However, it was originally introduced in 1970 by Holdgate and described the fourth climatic zone, additionally to three basic zones, previously recognized by Weyant in 1966 (Campbell \& Claridge, 1987). overview (Tin et al., 2009), to studies focused on certain species (Lynch et al., 2010; Coetzee \& Chown, 2015). Pfeiffer and Peter (2004) studied tourist impact on southern giant petrels at a site under VSG, Penguin Island. They suggested increasing the protection of this species. In an extensive analysis of 62 studies on different Antarctic species, Coetzee and Chown (2015) demonstrated that immediate behavioral response is not the biggest issue for local biodiversity; thus, management of tourist sites must be conducted on a case-by-case basis.

Meanwhile, a recent study on Gentoo penguins at one of the most visited sites, Port Lockroy, found almost a 25\% decrease in their breeding pairs over 21 years (Dunn et al., 2018). Although this decline was observed in both visited and unvisited colonies, the authors mention that penguins nesting in unvisited ones still moved to and from the sea through areas accessed by visitors. The paper assumes that even though the decline is a result of many factors, including climate change, "similar statistical support showed a significant link existed between year and visitors, with higher numbers of visitors negatively affecting penguin numbers". Although the long-term effects of disturbing Antarctic wildlife are still mostly unknown (Pfeiffer \& Peter, 2004; Chown et al., 2012), and the conclusions about tourist impact are often inconsistent (Bender et al., 2016; Holmes, 2007; Lynch et al., 2019), clear and thoughtful managing of sites with high tourism activity may help minimize current and future environmental impacts.

There are two types of measures aimed at protecting the Antarctic environment. One is represented by strict measures, such as the Antarctic Specially Protected Areas (ASPAs) and Antarctic Specially Managed Areas (ASMAs), and the other includes soft measures such as local site regulation without severe limitations (CEP, 2012). ASPA suggests complete closure of the site for tourists. On the other hand, the ASMA system is more flexible but too complicated to manage small tourist sites. Active development of a system with soft measures such as local small-scale area regulation started in the 1990s. Documents related to this system were aimed at securing sustainable visits to Antarctic tourist sites. First, in 1991 the 
Consultative Parties to the Antarctic Treaty (AT) adopted the Protocol on Environmental Protection to the Antarctic Treaty, the so-called Madrid Protocol (Protocol, 1993), which came into force in 1998.

Additionally, Parties adopted another document, the Guidance for Visitors to the Antarctic (ATCM, 1994). In the 2005 ATCM, in Resolution 5, Treaty Parties designed an instrument for managing sites with high tourism activity to protect wildlife, cultural and scientific values: Site Guidelines for Visitors. Also, the first four Guidelines were adopted that same year (ATCM, 2005a). Nowadays, there are 42 sites (Table 1) for which Visitor Site Guidelines have been developed.

In 2011, the ATCM stated that for environmental security, all visits to Antarctica should be conducted in accordance with the Antarctic Treaty, the Protocol on Environmental Protection to the Antarctic Treaty, and Measures and Resolutions considering the environmental protection, which the Antarctic Treaty adopted at Consultative Meetings (ATCM, 2011).

Nevertheless, some popular tourist places still lack their Visitor Site Guidelines. According to the 20172018 IAATO list of top 20 visited sites, the Ukrainian
Antarctic Akademik Vernadsky station (hereinafter Akademik Vernadsky station) located on Galindez Island got the $19^{\text {th }}$ place with its 4213 tourists per season (IAATO, 2018). Akademik Vernadsky station is one of the most popular Antarctic research stations regularly visited by tourists since 1968 (Fedchuk, 2013). Currently, tourist visits to the station are managed by the Ukrainian Antarctic National Program; however, the Visitor Site Guidelines have not been developed for the area around the station, despite the high tourist load and potential disturbance to the environment.

This paper aims to generate measures and instructions for minimizing possible visitor impacts on central Argentine Islands in the Wilhelm Archipelago (Galindez Island, Winter Island, and Skua Island) according to the Visitor Site Guidelines approach.

\section{Data and methods}

There is no definite structure for VSG text, nor any clear instructions of how they should be developed. In 2019 the Treaty Parties decided to create the Manual of Regulations and Guidelines Relevant to Tourism

Table 1. List of sites with Visitor Site Guidelines adopted at the Antarctic Treaty Consultative Meetings between 2005-2019. Data from Site Guidelines for Visitors (ATCM, 2019b)

\begin{tabular}{|c|c|}
\hline Sites under Visitor Site Guidelines & $\begin{array}{c}\text { Year of adoption } \\
\text { at the ATCM and No. } \\
\text { of sites adopted }\end{array}$ \\
\hline 1. Penguin Island; 2.Barrientos Island (Aitcho Islands); 3.Cuverville Island; 4.Jougla Point & $2005(4)$ \\
\hline $\begin{array}{l}\text { 5. Goudier Island, Port Lockroy; 6.Hannah Point; 7.NekoHarbour; 8.Paulet Island; } \\
\text { 9.Petermann Island; 10.Pléneau Island; 11.Turret Point; 12.Yankee Harbour }\end{array}$ & $2006(8)$ \\
\hline 13. Brown Bluff; 14.Snow Hill Hut & $2007(2)$ \\
\hline 15. Shingle Cove; 16.Devil Island-Vega Island;17.Whalers Bay; 18.Half Moon Island & $2008(4)$ \\
\hline $\begin{array}{l}\text { 19. Baily Head, Deception Island; 20.Telefon Bay (East), Deception Island; 21.Cape Royds; } \\
\text { 22.Wordie House, Winter Island; 23.Stonington Island; 24.Horseshoe Island; 25.Detaille Island }\end{array}$ & $2009(7)$ \\
\hline $\begin{array}{l}\text { 26. Torgersen Island; 27.Danco Island, Errera Channel; 28.Seabee Hook, Cape Hallett; } \\
\text { 29.Damoy Point }\end{array}$ & $2010(4)$ \\
\hline 30. Taylor Valley; 31.Northeast beach of Ardley Island; 32.Mawson's Huts and Cape Denison & $2011(3)$ \\
\hline $\begin{array}{l}\text { 33.D’Hainaut Island, Mikkelsen Harbour, Trinity Island; 34.Port Charcot, Booth Island; } \\
\text { 35.Pendulum Cove }\end{array}$ & $2012(3)$ \\
\hline 36.Orne Harbour; 37.Orne Islands & $2013(2)$ \\
\hline 38.Point Wild; 39.Yalour Islands & $2016(2)$ \\
\hline 40.Astrolabe Island;41.Georges Point (Rongé Island); 42.Portal Point & $2018(3)$ \\
\hline
\end{tabular}


and Non-Governmental Activities in the Antarctic Treaty area to ensure that such activities are carried out in full compliance with the Antarctic Treaty and its Protocol on Environmental Protection (ATCM, 2019a). In addition, the Treaty Parties also decided in 2019 to establish an intersessional contact group on strengthening the existing guidance for visitors to Antarctica and develop a proposal to adopt updated General Guidelines for Visitors to the Antarctic which are currently under consideration. Neither a manual has been created nor updated General Guidelines adopted yet, so in our work, we have drawn on the experience of existing VSGs, listed in Table 1.

Each Visitor Site Guidelines consist of a list of the most attractive values of the site ("Key Features") and five chapters. These are: 1) Description - it has a topography description and a list of the most important values of the site, including fauna, flora, historical/ cultural, or other values of an area; 2) Visitor Impact known and potential impacts from tourist activity; 3) Landing Requirements - general instructions and limitations for landing, including the maximum number of passengers; 4) Visitor Area - description of the area which is allowed or limited for walking, and 5) Visitor Code of Conduct - list of required or forbidden activities in the area.

"Key Features" are those values that primarily represent characteristics of the site that attract tourists. Each VSG specifies the most exciting values for tourists under "Key features", not considering their vulnerability or ecosystem importance. Some values that are to be protected are attractive to tourists simultaneously, though not all of these values can be visited by them. To determine what values to list in "Key Features", we analyzed relevant experience from other VSGs. Then all values mentioned in "Key Features" of the existing VSGs were categorized in several groups: geologic values, scenery, sea mammals, seabirds, vegetation, and historical and/or cultural values, and listed in Table 1 (see Appendix 1).

"Description" section gives a list of fauna and vegetation species, sometimes emphasizing which species of the site are rare or require protection, and other values of the area, i.e., geological or historical/ cultural values. Like any other section of the VSG, this chapter is not regulated by any AT or IAATO instruction and is written at the authors' discretion. Given this, we consider it necessary to indicate all the identified values of this area, which will determine the forms of tourism restriction in this area in our case.

To access the values (wildlife, geology, etc.) of the central Argentine Islands and prepare the draft of Visitor Site Guidelines for this region, we used data from Ukrainian Antarctic Expeditions (1996-2020). To determine which measures can minimize tourism impact on the site, we analyzed the experience of the existing 42 Visitor Site Guidelines. VSGs were accessed through the ATS website in March 2021 (https:// www. ats.aq/devAS/Ats/VisitorSiteGuidelines). ATCM and CEP Papers relevant to the study were accessed through the ATS website (http://www.ats.aq).

Tourism statistics were obtained directly from IAATO datasets and Overview of Antarctic Tourism 2018-2019 (IAATO, 2019; IAATO, 2020). Tourist operators submit information on each voyage and visit to landing sites, including information on the number of passengers landed and the activities at each site. Post-visit report forms developed by ATCMs (ATCM, 1997; ATCM, 2005b) are thus a valuable source of data for further analysis.

To calculate the maximum number of ships and visitors, we took into account that not only the daily limit is important, but the weekly as well, since the impact on some ecosystems is not always cumulative and daily load also matters.

We consulted skippers of yachts operating in this area (see the Acknowledgments), biology researchers, and other scientists who have equipment installed near suggested landing sites.

\section{Results and discussion}

\subsection{Main values ("Description")}

Among the wildlife of the central Argentine Islands, we defined the main values that may require protection. These are several seal species that have resting places or hunt in the region, seabirds including gentoo penguins (Pygoscelis papua (Forster, 1781) (Spheniscidae)) and diverse vegetation (for the extended list of species, see Appendix 2). 


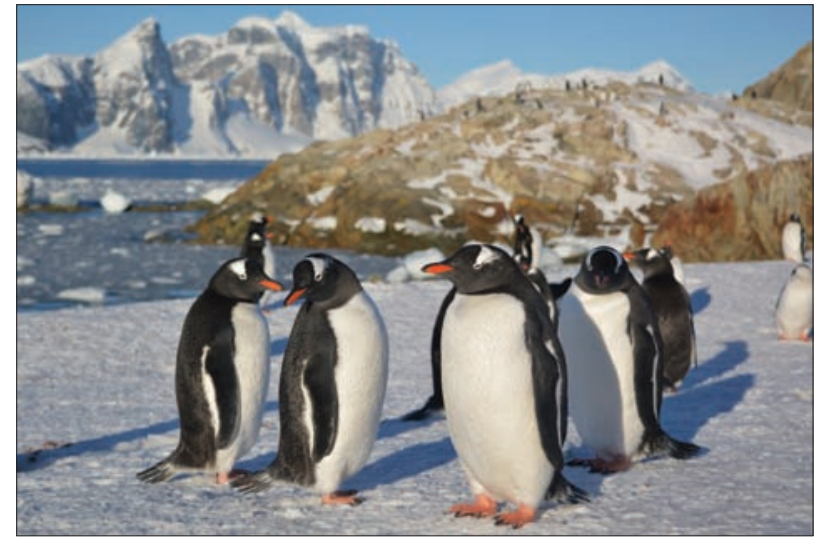

Figure 1. Gentoo penguins (Pygoscelis papua) on the Galindez Island (Argentine Islands). (The photo was taken by Andrii Zotov)

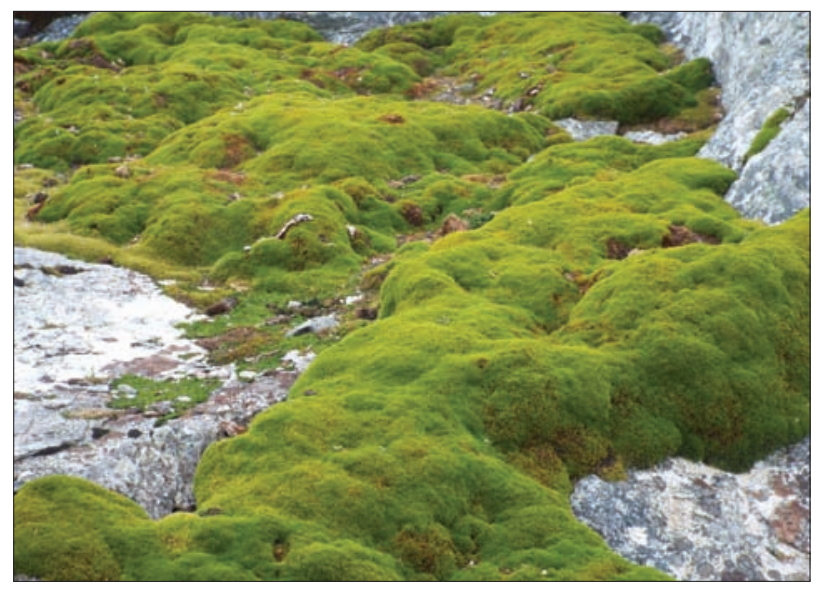

Figure 2. Fragment of the moss bank on Galindez Island. (The photo was taken by Ivan Parnikoza)

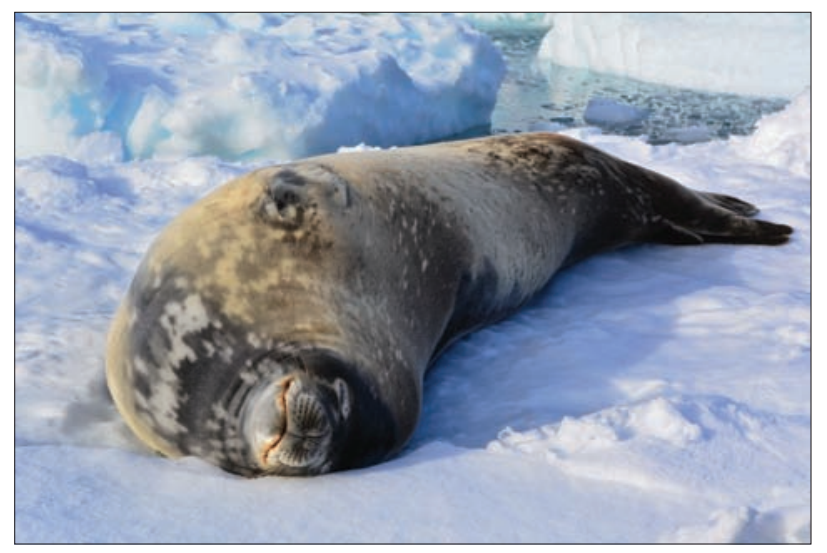

Figure 3. Weddell seal (Leptonychotes weddellii) resting on Skua Island (Argentine Islands). (Photo taken by Andrii Zotov)
Galindez Island is a place for one of the southernmost-recorded gentoo penguin ( $P$. papua) colonies (Fig. 1). Penguin colonies of Galindez Island are interesting not only for their numbers, which were almost 1000 nests in 2016 (Parnikoza et al., 2018) but also because they represent the influence of climate change on the Antarctic ecosystems. According to our data, the nesting area of gentoo penguins on the island is now expanding significantly (Parnikoza et al., 2018). In 2021 they formed a new sub-colony in the central part of Galindez Island.

There are many other birds on the central Argentine Islands, especially in the station vicinity. South polar skuas, kelp gulls, and snowy sheathbills are nesting near the Akademik Vernadsky station.

Other species of birds mentioned in the "Fauna" section (see Appendix 2) can often be seen on the islands. Imperial shags (Phalacrocorax atriceps, King, 1828 (Phalacrocoracidae)) and Adelie penguins (Pygoscelis adeliae (Hombron \& Jacquinot), 1841 (Spheniscidae)) rest in this region occasionally. In 2021 they attempted to nest on Galindez Island.

The central Argentine Islands is the resting place for numerous Antarctic fur seals Arctocephalus gazella (Peters, 1875) (Otariidae); and occasionally for southern elephant seals (Mirounga leonina (Linnaeus, 1758) (Phocidae)). Crabeater seal (Lobodon carcinophagus (Hombron \& Jacquinot, 1842) (Phocidae)) and leopard seal (Hydrurga leptonyx (Blainville, 1820) (Phocidae)) often rest on the pack-ice near these islands. Waters in the vicinity of gentoo colonies are leopard seal hunting grounds at the end of the summer season. Weddell seals (Leptonychotes weddellii (Lesson, 1826) (Phocidae)) regularly haul out on these islands as well (Fig. 3).

Vegetation is not only an important element of the surrounding landscape that is attractive to tourists (Fig. 2). It is important for the successful nesting of many Antarctic seabirds, which attracts tourists as well. The region is famous for its rich vegetation: different moss, lichens, and algae vegetation formations, among which there are ancient moss banks up to 3800 y.o. and even both Antarctic vascular plants: Antarctic hairgrass (Deschampsia antarctica E. Desv., 1854 (Poaceae)) and Antarctic pearlwort (Coloban- 


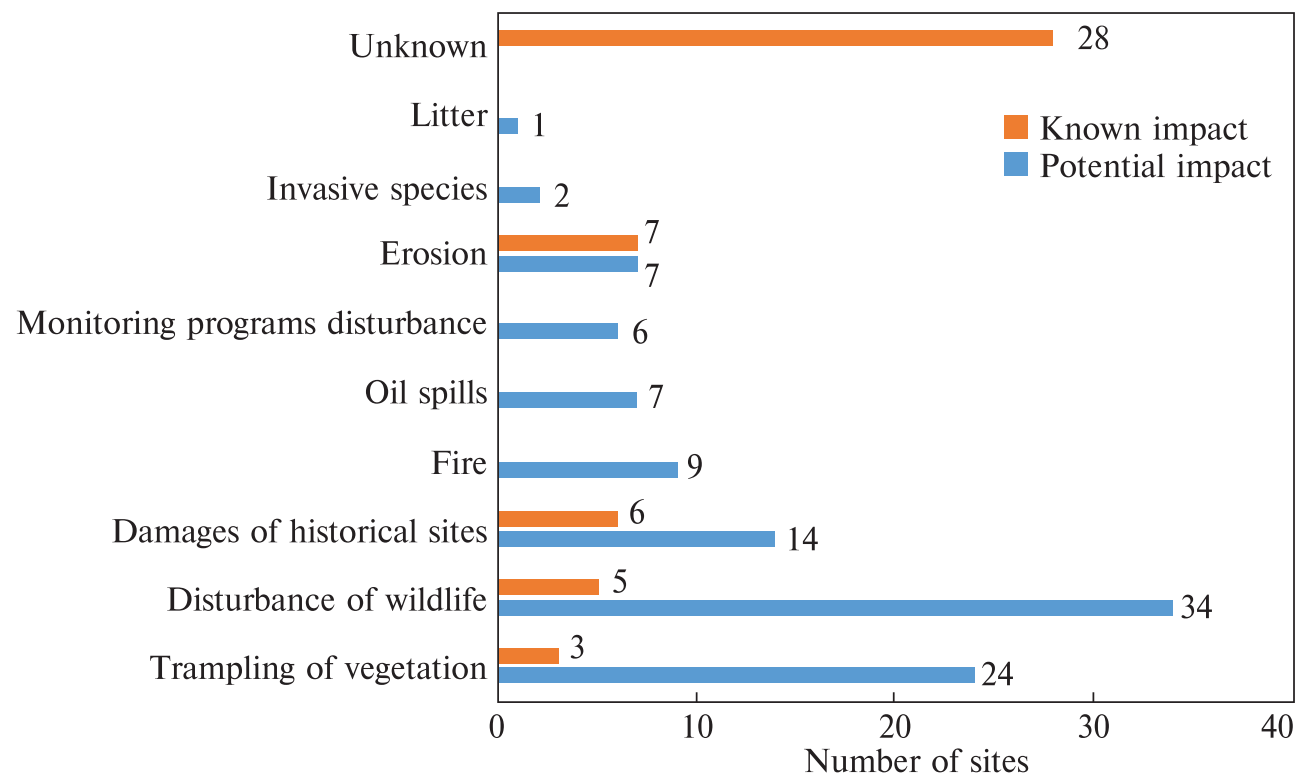

Figure 4. The known and potential impacts of tourists on the sites with Visitor Site Guidelines. Note: each site often has a number of impacts mentioned, so the overall number is not equal to the number of sites. Data from VSGs (http://atc.aq)

thus quitensis Kunth. Bartling, 1831 (Caryophyllaceae)) (Parnikoza et al., 2018). Tourists can see the vascular plants directly near Akademik Vernadsky station, where a monitoring site of these species is established. What is more, this site is the only known location in this region where a locally rare lichen (Himantormia lugubris (Hue) I.M. Lamb, 1964 (Parmeliaceae)) can be found. For the abovementioned reasons, vegetation is a priority value for this region.

Marine wildlife is also rich in the area. There are several areas of high value. The Skua Creek has an underwater rock (volcanic dike) about $3 \mathrm{~m}$ tall, with a base at a depth of up to $30 \mathrm{~m}$. The stone is covered with macrozoobenthos, including giant sponges and ascidians, surrounded by starfishes, ascidians, ophiuroids, and sea spiders. Another important area is situated near Galindez Island around the Penguin Point. Brown and red algae, especially the giant Phylogigas sp. (at depths up to $20 \mathrm{~m}$ ), the giant starfishes Macroptychaster accrescens (Koehler, 1920) (Astropectinidae), weighing up to $2 \mathrm{~kg}$, and Labidiaster annulatus Sladen, 1889 (Heliasteridae) were also found there. There are fields of gorgonian corals, sea urchins Ctenocidaris speciose Mortensen, 1910 (Cteno- cidaridae), giant polychaetes Flabegraviera mundata Gravier, 1906 (Flabelligeridae) and Eulagisca gigantea Monro, 1939 (Polynoidae), giant sponges Rossella racovitza Topsent, 1901 (Rossellidae), Ophiosparte gigas Koehler, 1922 (Ophiopyrgidae), and the flattened holothuria Bathyplotesfus civinculum Gutt, 1910 (Synallactidae) at depths from $20 \mathrm{~m}$ to $60 \mathrm{~m}$.

\subsection{Values attractive to tourists ("Key Features")}

As we found out, the most frequently available and thus widely advertised value is birds (including penguins): it is a key feature for $88 \%$ of sites. As mentioned earlier, there are many gentoo penguin colonies on the central Argentine Islands. Several subcolonies live very close to the Akademik Vernadsky station on the Marina Point and can be observed by tourists. Therefore, we can include penguins in the list of "Key features" of this region.

Three other values are the second most frequently mentioned: historical/cultural values (57\% of sites), marine mammals (57\%), and beautiful sceneries (52\%). In our VSG, we also followed common practice and listed sceneries (Woozle Hill on Galindez Island and 
a top of glacier on the Winter Island), marine mammals, and historical/cultural values (i.e., the Akademik Vernadsky station itself) as "Key Features".

Vegetation is the least frequent (17\% of all sites) listed key feature. This means that $83 \%$ of VSGs don't mention vegetation as a key feature of the site at all, despite it being present there much more frequently. Thus, both Antarctic vascular plants, D. antarctica and C.quitensis, grow in $17 \%$ and $26 \%$ of all sites, respectively. Terrestrial algae, mosses, and lichens are mentioned for $40 \%, 71 \%$, and $81 \%$ of sites, respectively. Mosses and lichens grow on all sites where vegetation is one of the "Key Features". Therefore, we can assume that if vegetation is included in the "Key features" of the site, the presence of mosses and lichens is primarily taken into account, rather than vascular plants or algae. Given the significant pedestrian impact of tourists on Antarctic vegetation and soils (Pertierra \& Hughes, 2013; Pertierra et al., 2013; Tejedo et al., 2012), we highlight the importance of vegetation for Argentine Islands and include it in the "Key Features" of the VSG.

\subsection{Visitor Impact}

To define known and potential impacts for VSG of the central Argentine Islands, we first analyzed known and potential impacts for all sites with Visitor Site Guidelines (Fig. 4).

Thus, for 28 (67\%) of the sites with VSGs, known tourist impacts were undefined. For other sites, three types of the known impacts were almost equally common: soil erosion for seven sites, damages of historical sites for six sites, and wildlife disturbance for five sites.

The least frequently mentioned known impact was trampling of vegetation: it was mentioned for only three sites (7\%), though mosses were found in 30 out of 42 sites (71\%). Thus, trampling of vegetation seems to be overlooked.

As for potential impacts from tourism to sites with VSG, disturbance of wildlife was the most widespread: mentioned for $34(81 \%)$ sites. Vegetation trampling was the second most frequent potential impact ( $57 \%$ of sites), though the vegetation was a "Key feature" for only $17 \%$ of all sites. Finally, damages of his- torical sites took the third place in the frequency of potential impacts (14 sites, i.e., 33\%).

When we further defined the impact of tourism on the central Argentine Islands, we distinguished between the known and potential impacts. Although the long-term effect on vegetation has not been adequately studied yet, from our experience, trampling is one of the biggest impacts from tourists. Thus, we emphasized the risk of vegetation trampling by adding it to a list of "known impacts" of VSG for this region. We also close some parts of the central Argentine Islands for visits.

The region is also rich in marine benthic biodiversity, and it has been shown that it can be seriously damaged while yachts are anchoring (Utevsky et al., 2014). Besides, 126 intraspecific taxa of phytoplankton were found here (Kuzmenko \& Ignatyev, 2008); there are six plots for regular studies of the development and taxonomic structure of phytoplankton near Galindez Island. Thus, "disturbance of underwater wildlife while anchoring" became the second known impact.

Following other VSGs that show wildlife disturbance as the major potential impact of tourists, we included this category in the list of potential impacts in VSG.

Tourists may also disturb monitoring equipment on the central Argentine Islands, including sensitive electromagnetic research complex, geodynamical polygons, and CCAMLR Environmental Monitoring Program (CEMP) cameras for monitoring gentoo penguins (Fedchuk et al., 2020). Thus, "monitoring program disturbance" was the second potential impact for VSG for the central Argentine Islands.

\subsection{Landing Requirements: maximum number of ships and visitors}

In this chapter, we depend upon the existing experience of landing regulation with in the Antarctic Treaty and VSG system, taking into account the logistic possibilities of the region described.

In 2009, Measure 15 ATCM XXXII prohibited ships carrying more than 500 passengers from landing in the Antarctic (ATCM, 2009). It has also established a maximum of 100 passengers on shore at any time. It should also be noted that Treaty Parties suggested a 
possibility of decreasing the maximum number of passengers if needed (ATCM, 2011). Landing requirements for sites under VSG are given in Table 2.

As for maximum visitors at a time, most sites have limits of 100 passengers at a time. However, the smallest Sites like 22.Wordie House, 26.Torgersen, and 38. Point Wild have limits as small as 20-40 visitors at a time. According to these data, and taking into account 1) small landing area, 2) ongoing scientific work at the Akademik Vernadsky station, 3) limited space inside the station, 4) numerous penguin colonies around the station, which may be disturbed, - and after careful consideration, we suggest limiting the maximum number of passengers on shore at any time to 36 people. In our practice, this means that usually, three or four small boats $(9-12$ tourists in each boat) land on Galindez Island simultaneously, and three groups go to the Akademik Vernadsky station for the trip. This number of people will not disrupt the working regime of the station and will protect the wildlife from disturbance by excessive noise and human presence.

We also highlight the limitations for yachts. To our knowledge, this has not been done for VSG before,

Table 2. Data on the maximum number of ships and visitors per day and at a time for sites under Visitor Site Guidelines, based on information provided in relevant VSGs (http://atc.aq)

\begin{tabular}{|c|c|c|c|c|}
\hline № & Name of Site & Ships per day & $\begin{array}{l}\text { Maximum passengers } \\
\text { per day } 1\end{array}$ & $\begin{array}{l}\text { Maximum } \\
\text { visitors at a time }\end{array}$ \\
\hline 1 & Penguin Island & 2 & 400 & 100 \\
\hline 2 & Barrientos Island (Aitcho Islands) & 2 & 400 & 100 \\
\hline 3 & Cuverville Island & 3 & 1500 & 100 \\
\hline 4 & Jougla Point & 3 & 1500 & 100 \\
\hline 5 & Goudier Island, Port Lockroy & 3 & 350 & 60 \\
\hline 6 & Hannah Point & $1 * * *$ & 200 & 100 \\
\hline 7 & Neko Harbour & 3 & $1200^{*}$ & 100 \\
\hline 8 & Paulet Island & 2 & 400 & 100 \\
\hline 9 & Petermann Island & 3 & $1200^{*}$ & 100 \\
\hline 10 & Pléneau Island & 3 & 1500 & 100 \\
\hline 11 & Turret Point & 2 & 400 & 100 \\
\hline 12 & Yankee Harbour & 3 & 1500 & 100 \\
\hline 13 & Brown Bluff & 3 & $900 * *$ & 100 \\
\hline 14 & Snow Hill Hut & $1 * * *$ & 200 & 100 \\
\hline 15 & Shingle Cove & 2 & 400 & 100 \\
\hline 16 & Devil Island-Vega Island & 2 & 400 & 100 \\
\hline 17 & Whalers Bay & 3 & $1200^{*}$ & 100 \\
\hline 18 & Half Moon Island & 3 & $1200^{*}$ & 100 \\
\hline 19 & Baily Head, Deception Island & 2 & 400 & 100 \\
\hline 20 & Telefon Bay (East), Deception Island & 3 & $1200^{*}$ & 100 \\
\hline 21 & Cape Royds & 2 & 400 & 100 \\
\hline 22 & Wordie House, Winter Island & 2 & $700^{* *}$ & 36 \\
\hline 23 & Stonington Island & 2 & $700^{* *}$ & 100 \\
\hline 24 & Horseshoe Island & 2 & $700 * *$ & 100 \\
\hline 25 & Detaille Island & 2 & $700^{* *}$ & 50 \\
\hline
\end{tabular}


End of Table 2

\begin{tabular}{|c|l|c|c|c|}
\hline № & \multicolumn{1}{|c|}{ Name of Site } & Ships per day & $\begin{array}{c}\text { Maximum passengers per } \\
\text { day1 }\end{array}$ & $\begin{array}{c}\text { Maximum } \\
\text { visitors at a time }\end{array}$ \\
\hline 26 & Torgersen Island & - & - & 40 \\
27 & Danco Island, Errera Channel & 3 & $1200^{*}$ & 100 \\
28 & Seabee Hook, Cape Hallett & 1 & 200 & 100 \\
29 & Damoy Point & - & $900^{* *}$ & 100 \\
30 & Taylor Valley & - & - & 100 \\
31 & Northeast beach of Ardley Island & - & - & 20 \\
32 & Mawson's Huts and Cape Denison & 3 & - & 100 \\
33 & D'Hainaut Island, Mikkelsen Harbour, Trinity Island & 2 & $1200^{*}$ & 100 \\
34 & Port Charcot, Booth Island & 3 & $900^{* *}$ & 100 \\
35 & Pendulum Cove & 3 & $1200^{*}$ & 100 \\
36 & Orne Harbour & 3 & 1500 & 100 \\
37 & Orne Islands & 2 & 1500 & 30 \\
38 & Point Wild & 2 & 1000 & - \\
39 & Yalour Islands & 2 & $700^{* *}$ & 100 \\
40 & Astrolabe Island & 3 & 1000 & 100 \\
41 & Georges Point, Rongé Island & 3 & $900^{* *}$ & 100 \\
42 & Portal Point & 1500 & \\
\hline
\end{tabular}

* No more than 2 carrying more than 200 passengers

** No more than 1 carrying more than 200 passengers

*** Defined as 1 ship at a time, maximum number of ships per day is not defined

though the number of yacht tours has increased recently (IAATO, 2019; IAATO, 2020). Thus, the maximum number of ships per day does not apply to yachts. We propose to limit the number of yachts to three per day. Unlike large ships, yachts usually come to the Argentine Islands for the whole day, sometimes two days; thus, they have no strict time limitations for visits. Yachts usually moor in small creeks near Galindez and Winter Islands, and their passengers can visit the Station at any convenient time. Besides that, yachts have only 12 people (maximum) on board, including crew, making even three visits per day safe for wildlife and convenient for the station staff. To address the needs of both the Station and local nature and in accordance with Article 3 of Protocol on Environmental Protection to the AT, the priority in visits (if more than three yachts per day want to visit the site) is given to yachts that support the scientific work of Ukrainian Antarctic Research Program.
Next, we propose to limit the speed of vessels near islands to $7 \mathrm{~km} / \mathrm{h}$. This minimizes the disturbance of marine mammals, especially crabeaters that rest on ice around the site. For this reason, it is prohibited for a boat to break the ice near the islands.

For wildlife and yacht safety, we identify different types of waters around the islands (see maps in Appendix 2): "anchor area", "no anchors" (with mooring allowed), and "closed area". Anchor area is allowed for passing through, mooring or anchoring. There are two anchor areas near Galindez Island: 1) the middle part of Stella Creek between Galindez Island and Winter Island; 2) a small bay near the northern part of Marina Point of Galindez Island in Meek Channel. No.1 is free for anchoring or mooring; yachts have been anchoring here for many years. No.2 is also a usual place for yachts for anchoring. However, we allow anchoring only in the western part 
of this bay because of sensitive magnetic equipment located in a hut nearby. This equipment requires no radio waves closer than $50 \mathrm{~m}$.

Next, we propose two "no anchors" areas. One is the northern part of Stella Creek because of smallscale underwater monitoring sites that can be damaged by anchors (Delegation of Ukraine, 2012; Fedchuk et al., 2020). The other is between Grotto Island and Marina Point (Galindez Island) due to another underwater monitoring site.

There are three "closed areas" near the central Argentine Islands. We propose closing Skua Creek and waters near Penguin Point (north-east point of Galindez Island) due to other underwater monitoring sites (Fedchuk et al., 2020). Next, a small part of the water area near the magnet hut on Galindez Island is also closed for the safety of the equipment.

To compare our proposed VSG with the existing practice, we found five sites with VSG located near our region: № 9, 10, 22, 34, 39. Three of them are highly visited places (№ 9, 10, and 34), with 9001500 visitors allowed per day (every day during the week), while sites № 22 and № 39 limit passengers to 700 per day. A slightly more distinct site (5. Goudier Island, Port Lockroy) that has a museum takes maximum 350 visitors per day. In general, it corresponds to our suggestions of limits. However, the peculiarity of our region is that we have a working scientific station. Other Sites under VSG don't have stations, except museums like Port Lockroy.

Thus, there are many highly visited places in the Wilhelm Archipelago, where the Argentine Islands are located. The Argentine Islands is one of the top-20 visited places in maritime Antarctica (CEP, 2012). Therefore, we define the maximum number of ships/week as two (not including yachts), with the maximum number of landing passengers as 270/day (not including yachts' passengers). This limitation was estimated empirically and is a result of discussions with scientists and engineers, chiefs of winter seasons at the Akademik Vernadsky station. The daily limit corresponds to the existing (see Table 2) practice. Two big ships a week is optimal, as we know from practice that more ships a week (or visitors a day) make the work of scientists and staff more difficult.

\subsection{Visitor Area}

For a long time, the entire tourist flow from large tourist vessels was concentrated on the site of the Akademik Vernadsky station and the Wordie House. Only short walks were made to the top of the glacier of Winter Island. Landing and visiting Wordy House is governed by VSG № 22 for this site (https://www. ats.aq/devAS/Ats/Guideline/40a61086-5fc6-4bde9249-b06f6f8f8fde).

In the case of the Akademik Vernadsky station, there is a need to decrease the tourist load of the station and to create an additional visitor area. Previously, during visits from yachts, the whole area was kept open for visiting, which threatened all the abovementioned values of the region.

To minimize the visitor impact and regulate the tourist flow, we suggest two tourist routes for guided walking area. They cover the most interesting points of Galindez Island (Fig. 5) and the existing trail on Winter Island. The route on Galindez Island includes historically significant objects, spectacular view points, interesting Antarctic vegetation, and places for observing wildlife without disturbance. Thus, Galindez Island is proposed to become half-closed, except for tourist routes and the area around the station and near historically significant objects (see maps in Ap-

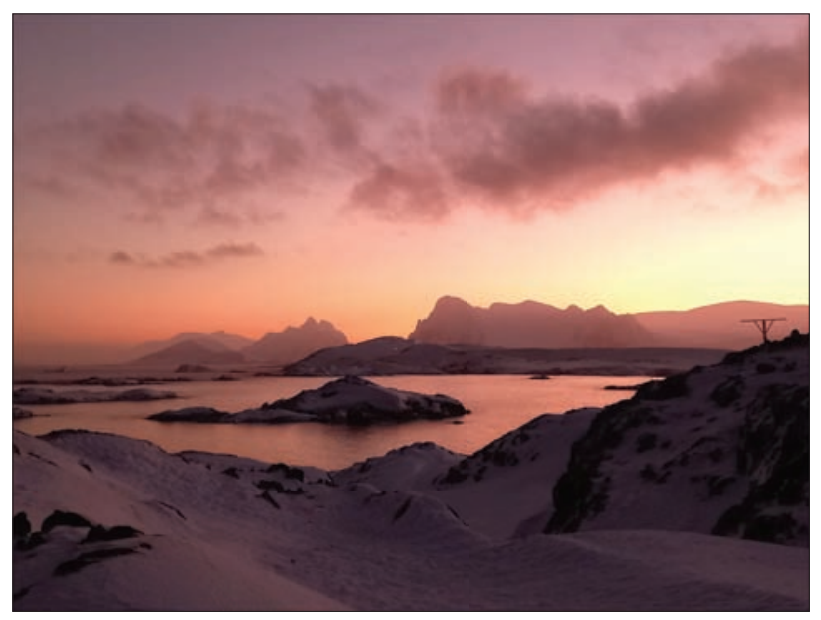

Figure 5. View from the tourist route on Galindez Island to the neighbouring islands and the mainland. (The photo was taken by Hanna Yevchun) 
pendix 2). On Winter Island, we keep the existing trail for walking on top of the glacier open for visitors. All other territories are forbidden to enter to not damage numerous vulnerable mosses and lichens, disturb scientific plots that sometimes have no markings visible for tourists, and to avoid dangerous hillsides. Skua Island is not visited by tourists nowadays; therefore, we propose to keep it closed to help preserve its biodiversity.

To protect the fragile vegetation of Galindez Island, we are closing this island except for certain areas (see Appendix 2, Figs. 1 and 2) and tourist routes. These trails were carefully checked in the field so that they do not cross mosses and penguin colonies.

Note that all areas closed to tourists in developing the VSG, except Marina Point, are subjected to be included in the proposed ASPA "Argentine Islands and Kyiv Peninsula Region".

\subsection{Visitor Code of Conduct and Cautionary notes}

These rules run in accordance with the General Code of Conduct in the Antarctic and describe onshore behavior and also permissions and prohibitions for tourists visiting Antarctic sites. All the existing VSGs include these rules; therefore we also mention these rules in the relevant paragraph of the proposed VSG (Appendix 2).

The only paragraph added warns about snow and ice overhangs made of undercut ice around the coastline: boats cruising around the islands should be cautious about these overhangs.

\section{Conclusions}

Given the high number of visitors to the central Argentine Islands, we have developed measures to minimize the impact of tourism on its values using the VSG approach. Based on studies in this region, the main values of wildlife have been identified, emphasizing the value of the local vegetation. The key features of the region described are vegetation, seals and penguin colonies, glacier scenery, and Ukrainian yearround Akademik Vernadsky station. Threats to these values were also defined: two known impacts ("Trampling of vegetation" and "Disturbance of underwater wildlife while yachts are anchoring") and two potential impacts ("Disturbance of nesting sea birds and mammals" and "Disturbance of monitoring programs"). We also developed landing requirements for the area, including a limit for the number of visitors. We believe that number of visitors to the site should not exceed 36 at a time and 270 per day (not including yachts' passengers), with no more than two ships allowed per week. For the first time for Visitor Site Guidelines, we suggest limits for yachts: no more than three yachts per day with no additional week limits. To decrease tourist load and organize tourist flow, we propose two tourist trails: a new route for Galindez Island and the existing trail on Winter Island. All measures suggested for managing this region were described in the Visitor Site Guidelines attached (Appendix 2). This VSG will be submitted to the next Antarctic Treaty Consultative Meeting. It should also be noted that as recommended by the Representatives of the ATCM in its Resolution 5 (ATCM, 2005a), "texts of Site Guidelines can be modified readily to reflect readily changing environmental circumstances". In 2019, the Treaty Parties decided through its Resolution (ATCM, 2019b) that VSG for each site must be reviewed and revised promptly in two cases: if there are changes in the levels and types of visits, or in response to any demonstrable or likely environmental impacts. Therefore, VSGs are subject to change if necessary.

Author contributions. IP, AF, ED, VK: conceptualization. HE: introduction, methodology, data analysis, the original draft, visualization, writing. IP, AF, HE: investigation, data analysis, and composition of Appendix 2. IK, IP, HE, ED, VK: project administration, editing. IP: conclusions.

Acknowledgments. This paper was conducted within The State Special-Purpose Research Program in Antarctica for 2011-2020 of the State Institution National Antarctic Scientific Center, Ministry of Education and Science of Ukraine. We are grateful to Brice Monégier du Sorbier, skipper of Podorange, and Piotr Kuźniar, skipper of Selma, for their detailed 
commentary on landing requirements, and Dr. Andrii Zotov for photos from the Argentine Islands. We also appreciate the suggestions of Andrii Utevsky on behalf of damages to wildlife from anchoring.

Conflict of Interest. The authors declare that they have no conflict of interest.

\section{References}

ATCM. (1994). Guidance for Visitors to the Antarctic (R1). Retrieved April 5, 2021, from http://www.ats.aq/documents/recatt/Att245_e.pdf

ATCM. (1997). Trial report form for tourism and NGO activities in Antarctic Treaty Area (R3). Retrieved April 5, 2021, from http://www.ats.aq/documents/recatt/Att074_e.pdf

ATCM. (2005a). Annex to Resolution 5. List of current Site Guidelines. In Site Guidelines for Visitors. Retrieved April 5, 2021, from http://www.ats.aq/documents/recatt/Att254_e.pdf

ATCM. (2005b). Annex to Resolution 6. Post visit report form. In Site Guidelines for Visitors. Retrieved April 5, 2021, from http://www.ats.aq/documents/recatt/Att267_e.pdf

ATCM. (2009). Landing of Persons from Passenger Vessels in the Antarctic Treaty Area. Retrieved April 5, 2021, from https://ats.aq/devAS/Meetings/Measure/432?s $=1 \&$ from $=0$ $4 / 17 / 2009 \&$ to $=04 / 17 / 2009 \&$ cat $=14 \&$ top $=0 \&$ type $=0 \&$ stat $=$ $0 \& \mathrm{txt}=\&$ curr $=0 \&$ page $=1$

ATCM. (2011). General guidelines for visitors to the Antarctic (R3). Retrieved April 5, 2021, from http://www.ats.aq/ documents/recatt/Att483_e.pdf

ATCM. (2019a). Manual of Regulations and Guidelines Relevant to Tourism and Non-Governmental Activities in Antarctica (Decision 6). Retrieved April 5, 2021, from https://www.ats. aq/devAS/Meetings/Measure/699

ATCM. (2019b). List of sites subject to Site Guidelines (R2). http://www.ats.aq/documents/recatt/Att668_e.pdf

Bargagli, R. (2020). Terrestrial ecosystems of the Antarctic Peninsula and their responses to climate change and anthropogenic impacts. Ukrainian Antarctic Journal, 2, 84-97. https://doi.org/10.33275/1727-7485.2.2020.656

Bender, N. A., Crosbie, K., \& Lynch, H. J. (2016). Patterns of tourism in the Antarctic Peninsula region: a 20-year analysis. Antarctic Science, 28(3), 194-203. https://doi.org/10.1017/ S0954102016000031

Campbell, I. B., \& Claridge, G. G. C. (1987). Antarctica: soils, weathering processes and environment (1st ed.), Vol. 16. Elsevier Science. https://www.elsevier.com/books/antarcticasoils-weathering-processes-and-environment/campbell/9780-444-42784-7

Chown, S. L., Lee, J. E., Hughes, K. A., Barnes, J., Barrett, P. J., Bergstrom, D. M., Convey, P., Cowan, D. A., Crosbie, K., Dyer, G., Frenot, Y., Grant, S. M., Herr, D., Kennicutt II, M. C., Lamers, M., Murray, A., Possingham, H. P., Reid, K., Riddle, M. J., ... Wall, D. H. (2012). Challenges to the future conservation of the Antarctic. Science, 337(6091), 158-159. https://doi.org/10.1126/science.1222821

Coetzee, B. W. T., \& Chown, S. L. (2015). A meta-analysis of human disturbance impacts on Antarctic wildlife. Biological Reviews, 91(3), 578-596. https://doi.org/10.1111/brv.12184

Committee for Environmental Protection. (2012). CEP Tourism Study.Tourism and non-governmental activities in the Antarctic: environmental aspects and impacts. https://www.ats. aq/documents/ATCM35/att/ATCM35_att067_e.doc

Delegation of Ukraine. (2012). The first site of the Marine Protected Area network in the Akademik Vernadsky Station region: Argentine Islands, Skua Creek (WG-EMM-12/25). In Report of the Working Group on Ecosystem Monitoring and Management. CCAMLR. https://www.ccamlr.org/en/system/ files/e-sc-xxxi-a06.pdf

Dunn, M. J., Forcada, J., Jackson, J. A., Waluda, C. M., Nichol, C., \& Trathan, P. N. (2018). A long-term study of gentoo penguin (Pygoscelis papua) population trends at a major Antarctic tourist site, Goudier Island, Port Lockroy. Biodiversity and Conservation, 28(1), 37-53. https://doi.org/10. 1007/s10531-018-1635-6

Fedchuk, A. (2013). The development of tourism at Faraday/Vernadsky station: changes in governance and visitor patterns. Polar Record, 49(3), 286-290. https://doi.org/10.1017/ S0032247412000599

Fedchuk, A., Sinna, O., Milinevsky, G., \& Utevsky, A. (2020). The harmonization of small-scale marine spatial protection in the Argentine Islands area (Antarctic Peninsula) under the Antarctic Treaty System. Ukrainian Antarctic Journal, 1, 111-119. https://doi.org/10.33275/1727-7485.1.2020.384

Holmes, N. D. (2007). Comparing king, gentoo, and royal penguin responses to pedestrian visitation. Journal of Wildlife Management, 71(8), 2575-2582. https://doi.org/10. 2193/2005-715

Hughes, K. A., Pescott, O. L., Peyton, J., Adriaens, T., Cottier-Cook, E. J., Key, G., Rabitsch, W., Tricarico, E., Barnes, D. K. A., Baxter, N., Belchier, M., Blake, D., Convey, P., Dawson, W., Frohlich, D., Gardiner, L. M., González-Moreno, P., James, R., Malumphy, C., ... Roy, H. E. (2020). Invasive non-native species likely to threaten biodiversity and ecosystems in the Antarctic Peninsula region. Global Change Biology, 26(4), 2702-2716. https://doi.org/10.1111/gcb.14938

IAATO. (2018). Report on IAATO operator use of Antarctic Peninsula Landing Sites and ATCM visitor site guidelines, 201718 season (IP 72). https://iaato.org/wp-content/uploads/2020/ 03/ATCM41_ip72_e.pdf

IAATO. (2019). IAATO overview of Antarctic tourism: 2018 19 season and preliminary estimates for 2019-20 season (IP140 rev.1). https://iaato.org/wp-content/uploads/2020/03/IP140IAATO-Overview-of-Antarctic-Tourism-2018-19-Seasonand-Preliminary-Estimates-for-2019-20-Season.pdf

IAATO. (2020). IAATO Antarctic visitor figures 2019-2020. https://iaato.org/wp-content/uploads/2020/07/IAATO-onAntarctic-visitor-figures-2019-20-FINAL.pdf 
Kuzmenko, L. V.,\& Ignatyev, S. M. (2008). Species diversity of phytoplankton in the waters of Argentine Islands (Antarctica). Algologia, 18(2), 198-212. (In Russian)

Lynch, H. J., Fagan, W. F., \&Naveen, R. (2010). Population trends and reproductive success at a frequently visited penguin colony on the western Antarctic Peninsula. Polar Biology, 33, 493-503. https://doi.org/10.1007/s00300-009-0726-y

Lynch, M. A., Youngflesh, C., Agha, N. H., Ottinger, M. A., \& Lynch, H. J. (2019). Tourism and stress hormone measures in Gentoo Penguins on the Antarctic Peninsula. Polar Biology, 42, 1299-1306. https://doi.org/10.1007/s00300-01902518-Z

Naveen, R., Forrest, S. C., Dagit, R. G., Blight, L. K., Trivelpiece, W. Z., \& Trivelpiece, S. G. (2001). Zodiac landings by tourist ships in the Antarctic Peninsula region, 1989-99. Polar Record, 37(201), 121-132. https://doi.org/10.1017/s0032 247400026942

Ochyra, R., Lewis-Smith, R. I. L., \& Bednarek-Ochyra, H. (2008). The illustrated Moss Flora of Antarctica. Cambridge University Press.

Parnikoza, I., Berezkina, A., Moiseyenko, Y., Malanchuk, V., \& Kunakh, V. (2018). Complex survey of the Argentine Islands and Galindez Island (Maritime Antarctic) as a research area for studying the dynamics of terrestrial vegetation. Ukrainian Antarctic Journal, 1(17), 73-101. https://doi.org/ 10. 33275/1727-7485.1(17).2018.34

Pertierra, L. R., \& Hughes, K. A. (2013). Management of Antarctic Specially Protected Areas: permitting, visitation and information exchange practices. Antarctic Science, 25(4), 553-564. https://doi.org/10.1017/S0954102012001204
Pertierra, L. R., Lara, F., Tejedo, P., Quesada, A., \& Benayas, J. (2013). Rapid denudation processes in cryptogamic communities from Maritime Antarctica subjected to human trampling. Antarctic Science, 25(2), 318-328. https://doi.org/ 10.1017/s095410201200082x

Pfeiffer, S., \& Peter, H. U. (2004). Ecological studies toward the management of an Antarctic tourist landing site (Penguin Island, South Shetland Islands). Polar Record, 40(4), 345-353. https://doi.org/10.1017/s0032247404003845

Protocol on Environmental Protection to the Antarctic Treaty. (1993). Polar Record, 29(170), 256-275. https://doi. org/10.1017/s0032247400018763

Riffenburgh, B. (Ed.) (2006). Encyclopedia of the Antarctic. Routledge.

Tejedo, P., Pertierra, L. R., Benayas, J., Convey, P., Justel, A., \& Quesada, A. (2012). Trampling on maritime Antarctica: can soil ecosystems be effectively protected through existing codes of conduct? Polar Research, 31(1), 10888. https://doi. org/10.3402/polar.v31i0.10888

Tin, T., Fleming, Z. L., Hughes, K. A., Ainley, D. G., Convey, P., Moreno, C. A., Pfeiffer, S., Scott, J., \& Snape, I. (2009). Impacts of local human activities on the Antarctic environment. Antarctic Science, 21(1), 3-33. https://doi.org/10.1017/ S0954102009001722

Utevsky, A., Sennaya, E., \& Kolesnykova, M. (2014). Realization of the Marine Protected Area network in the Akademik Vernadsky Station region (WG-EMM-14/41). CCAMLR. https:// www.ccamlr.org/en/wg-emm-14/41

Received: 7 April 2021 Accepted: 1 July 2021

Г. Свчун ${ }^{1,2, *}$, Є. Дикий ${ }^{1}$, I. Козерецька' ${ }^{1}$,

А. Федчук ${ }^{1}$, В. Карамушка ${ }^{2}$ I. Парнікоза ${ }^{1,2,3}$

${ }^{1}$ Державна установа Національний антарктичний науковий центр МОН України, м. Київ, 01601, Україна

${ }^{2}$ Національний університет Києво-Могилянська академія, м. Київ, 04655, Україна

${ }^{3}$ Інститут молекулярної біології і генетики НАН України, м. Київ, 03143, Україна

* Автор для кореспонденції: hanna.yevchun@gmail.com

Мінімізація туристичного впливу на екосистему Аргентинських островів, Антарктичний півострів, за допомогою підходу регулювання відвідувачів

Анотація. Кількість туристів, які відвідують Антарктику, постійно зростає з 2010 року. Ці візити в основному концентруються лише в кількох місцях, збільшуючи можливий вплив на довкілля. Однією з туристичних гарячих точок Антарктики є Аргентинські острови в архіпелазі Вільгельма. Вони входять в топ-20 найбільш відвідуваних місць Антарктики і складаються з островів Галіндез, Вінтер та Скуа. Місце відоме своєю дикою природою, багатою рослинністю (давні мохові банки, лишайники, популяції перлинниці Colobanthus quitensis та щучника антарктичного Deschampsia antarctica), вражаючими краєвидами та включає одну з найстаріших дослідницьких баз в Антарктиці - Українську антарктичну станцію «Академік Вернадський». До цього моменту не було розроблено заходів щодо зниження впливу туристів на цінності цього регіону. На основі підходу Правил відвідування та базуючись на результатах численних досліджень, було визначено головні цінності регіону та встановлено ті з них, які можуть бути відкриті для туристів. Так, окрім таких загальноприйнятих цінностей як морські птахи і ссавці, додано рослинність. Оцінено загрози для цих 
компонентів цінності регіону, які поділено на відомі та потенційні впливи. Проаналізовано та розроблено вимоги до висадки на дану територію, включаючи найважливішу вимогу - кількість відвідувачів. Ми вважаємо, що максимальна кількість повинна становити 36 осіб за одну висадку та 270 осіб за день, не рахуючи пасажирів яхт. Вперше для Правил відвідування було запропоновано обмежити кількість яхт, які відвідують туристичну локацію, до трьох на день. Щоб розвантажити станцію і водночас сконцентрувати туристів у досліджуваному регіоні, ми запропонували дві туристичні стежки: одну для острова Галіндез, другу - вже наявну на острові Вінтер. У Додатку 2 наводиться підготовлений проєкт Правил туристичного відвідування центральних Аргентинських островів.

Ключові слова: острів Галіндез, острів Вінтер, острів Скуа, антарктичний туризм, вплив на довкілля, Договір про Антарктику

\section{APPENDIX 1}

Table 1. Key features of sites with Visitor Site Guidelines: geology, scenery, historical or cultural, sea mammals, seabirds and vegetation. Data from documents at https://ats.aq

\begin{tabular}{|c|c|c|c|c|c|c|c|}
\hline & $\begin{array}{l}\text { Name of the Site under } \\
\text { Visitor Site Guidelines }\end{array}$ & Geology & Scenery & $\begin{array}{l}\text { Historical / } \\
\text { cultural }\end{array}$ & $\begin{array}{c}\text { Sea } \\
\text { mammals }\end{array}$ & Seabirds & Vegetation \\
\hline 1 & Penguin Island & + & - & + & - & + & + \\
\hline 2 & Barrientos Island (Aitcho Islands) & + & - & - & + & + & + \\
\hline 3 & Cuverville Island & - & + & + & - & + & - \\
\hline 4 & Jougla Point & - & + & + & - & + & - \\
\hline 5 & Goudier Island & - & + & + & - & + & - \\
\hline 6 & Hannah Point & + & - & - & + & + & + \\
\hline 7 & Neko Harbour & - & + & + & - & + & - \\
\hline 8 & Paulet Island & - & + & + & - & + & - \\
\hline 9 & Petermann Island & - & + & + & - & + & - \\
\hline 10 & Pleneau Island & + & + & - & - & + & - \\
\hline 11 & Turret Point & + & - & - & + & + & - \\
\hline 12 & Yankee Harbour & - & - & + & - & + & - \\
\hline 13 & Brown Bluff & + & - & + & - & + & - \\
\hline 14 & Snow Hill Hut & + & - & + & - & + & - \\
\hline 15 & Shingle Cove & - & - & - & + & + & + \\
\hline 16 & Devil Island - Vega Island & + & + & - & + & + & - \\
\hline 17 & Whalers Bay & - & - & + & + & + & - \\
\hline 18 & Half Moon Island & - & - & - & + & + & + \\
\hline 19 & Baily Head, Deception Island & - & - & - & - & + & - \\
\hline 20 & Telefon Bay (East), Deception I. & + & + & - & + & - & - \\
\hline 21 & Cape Royds & - & + & + & + & + & - \\
\hline 22 & Wordie House, Winter Island & - & + & - & - & + & - \\
\hline 23 & Stonington Island & - & + & + & - & - & - \\
\hline 24 & Horseshoe Island & - & - & + & - & + & - \\
\hline 25 & Detaille Island & - & - & + & - & - & - \\
\hline
\end{tabular}


End of Table 1

\begin{tabular}{|c|c|c|c|c|c|c|c|}
\hline & $\begin{array}{l}\text { Name of the Site under } \\
\text { Visitor Site Guidelines }\end{array}$ & Geology & Scenery & $\begin{array}{c}\text { Historical / } \\
\text { cultural }\end{array}$ & $\begin{array}{c}\text { Sea } \\
\text { mammals }\end{array}$ & Seabirds & Vegetation \\
\hline 26 & Torgersen Island & - & - & + & + & + & - \\
\hline 27 & Danco Island, Errera Channel & - & + & - & + & + & - \\
\hline 28 & Seabee Hook, Cape Hallett & - & + & - & + & + & - \\
\hline 29 & Damoy Point & - & + & + & + & + & - \\
\hline 30 & Taylor Valley & + & + & + & - & - & - \\
\hline 31 & Northeast beach of Ardley Island & - & - & - & + & + & - \\
\hline 32 & Mawson's Huts and Cape Denison & - & - & + & + & + & - \\
\hline 33 & $\begin{array}{l}\text { D’Hainaut Island, Mikkelsen Harbour, } \\
\text { Trinity Island }\end{array}$ & - & - & + & + & + & - \\
\hline 34 & Port Charcot, Booth Island & - & + & + & + & + & - \\
\hline 35 & Pendulum Cove & + & - & + & - & - & - \\
\hline 36 & Orne Harbour & - & + & - & + & + & + \\
\hline 37 & Orne Islands & - & + & - & + & + & - \\
\hline 38 & Point Wild & + & - & + & + & + & - \\
\hline 39 & Yalour Islands & - & + & + & + & + & + \\
\hline 40 & Astrolabe Island & - & - & - & + & + & - \\
\hline 41 & Georges Point, Rongé Island & - & + & - & + & + & - \\
\hline 42 & Portal Point & - & + & - & + & + & - \\
\hline
\end{tabular}

\section{APPENDIX 2}

Visitor Site Guidelines for the Argentine Islands

Key Features

- Year-round Akademik Vernadsky station (Ukraine) and Historic British Base F, Wordie House.

- Seal species and one of the southernmost recorded gentoo penguin colonies.

- Populations of both species of vascular plants growing in Antarctica, moss banks \&lichens.

- Glacial scenery.

\section{Description}

\section{Topography}

The group of three large islands in the Argentine Islands $\left(65^{\circ} 15^{\prime} \mathrm{S} ; 64^{\circ} 16^{\prime} \mathrm{W}\right)$, lying 5-6 $\mathrm{km} \mathrm{NW}$ of the Antarctic Peninsula (Graham Coast, Kyiv Peninsula), e.g., Galindez (the largest one), Winter, and Skua.

There are relict glaciers, post-glacier landforms such as moraines and glacier rocks, numerous rock outcrops, freshwater reservoirs, and ephemeral springs on the islands.

\section{Fauna}

Confirmed breeders: gentoo penguin (Pygoscelis papua), south polar skua (Catharacta maccormicki), kelp gull (Larus dominicanus), Wilson's storm petrel (Oceanites oceanicus). 
Other birds: Adelie penguin (Pygoscelis adeliae), imperial shag (Phalacrocorax atriceps), snow petrel (Pagodroma nivea), southern fulmar (Fulmarus glacialoides), southern giant petrel (Macronectes giganteus), Antarctic petrel (Thalassoica antarctica), Antarctic tern (Sterna vittata), Arctic tern (Sterna paradisaea), brown skua (Stercorarius antarcticus).

Terrestrial invertebrates: Antarctic midge (Belgica antarctica), mites, water bears (Tardigrada sp.), springtails (Collembola sp.), nematodes, rotifers, etc.

Regularly haul out: Weddell seal (Leptonychotes weddellii), Antarctic fur seal (Arctocephalus gazella).

Also visited by: southern elephant seal (Mirounga leonina).

On the pack-ice: crabeater seal (Lobodon carcinophaga) and leopard seal (Hydrurga leptonyx) (the latter also hunts near penguin colonies).

The waters are inhabited by many species of oceanic invertebrates and fishes.

\section{Flora}

The islands are a botanical hotspot of the Antarctic Peninsula, hosting specific ornithogenic populations of both native vascular plants Antarctic hair grass (Deschampsia antarctica) and rare Antarctic pearlwort (Colobanthus quitensis), fruticose lichen and moss cushion subformations, crustose lichens, moss carpets and valuable communities of ancient moss turf sub-formations (moss banks up to 3800 y.o.), algae and snow algae formations. In the whole Argentine Islands area, the region is the only currently known location of the lichen Himantormia lugubris.

\section{Other}

The year-round Akademik Vernadsky station (Ukraine) is situated in the NW of the Galindez Island, on the Marina Point. The Historic British Base F (Wordie House) on the Winter Island is designated as a Historic Site and Monument No. 62 under the Antarctic Treaty.

CCAMLR Environmental Monitoring Program (CEMP) sites, managed by Ukraine, are located on Galindez Island (see maps, Figs. 1, 2). The gentoo penguins are monitored for population size and breeding success.

\section{Visitor Impact}

\section{Known impact}

Trampling of vegetation, especially moss banks and lichens. Disturbance of underwater wildlife by anchoring yachts.

\section{Potential impact}

Disturbance of nesting sea birds and mammals. Disturbance of monitoring program.

\section{Landing Requirements}

\section{Ships $^{1}$ and yachts ${ }^{2}$}

Maximum visitors per day: 270

Maximum ships per week: 2

Yachts per day: 3

\footnotetext{
${ }^{1}$ A ship is defined as a vessel that carries more than 12 passengers.

${ }^{2}$ A yacht is defined as a vessel that carries up to 12 passengers.
} 
Comments:

The above-mentioned restrictions apply in the case of visiting Akademik Vernadsky station (Ukraine), while yachting and small boat cruising without landing within the internal waters of the Argentine Islands are not restricted. Also, see the landing requirements for ships specified by the Visitor Guidelines for the Winter Island (Resolution 1 (2010)).

Tour vessels and yachts visiting the area should provide advance notice of their visit schedule to National Programs operating in the area, particularly to Akademik Vernadsky station Leader. Priority is given to vessels supporting science activities.

For the safety of marine mammals, the speed limit within the coastal waters of the Argentine Islands is 7 $\mathrm{km} / \mathrm{hr}$. Yachts and small boats cruising should avoid disturbing seal and bird colonies and should keep the distance of approximately $30 \mathrm{~m}$ from the Closed sea areas. Tour vessels are forbidden to enter / pass through or anchor in the Closed sea areas, except the part of the Meek Channel between Galindez Island and Grotto Island, where only scientific and supply vessels are allowed to anchor.

\section{Anchorage}

Tour vessels visiting the Argentine Islands should lie at a safe distance in Penola Strait or French Passage, while visitors go ashore in small boats through Meek Channel, using either a basic anchor zone in Stella Creek or an auxiliary anchor zone in Meek Channel, mostly accessible during the NW wind (see map).

Breaking ice to steer a vessel or a boat is forbidden within the Argentine Islands' internal waters to accommodate resting crabeaters.

\section{Mooring}

Mooring is permitted in specially equipped places and only within the coastal strip marked on the map as a "mooring site". Yachts can be tied up to the mooring steel poles on the shore.

Vessels moor at their discretion within the permitted zones. The Akademik Vernadsky station personnel is not responsible for possible damages to vessels or passengers caused by improper choice of anchorage/mooring place or bad weather.

\section{Visitors}

Visitors are divided into groups; the total number of people on each landing point or tourist route simultaneously should not be more than 36 , not including staff and station guides.

Curfew time period (from/to), to establish a rest period for wildlife: 22:00-04:00.

Visitors enter this area at their own risk. Neither the personnel from Akademik Vernadsky station nor the National Antarctic Scientific Center nor the Ukraine authorities will be liable for any personal injury or damage to property sustained while they stay within the area.

\section{Landing Requirements}

\section{Landing area}

Depending on the sea ice, snow coverage conditions, and the working schedule of the Akademik Vernadsky station, there are several landing sites marked on the map as follows:

Galindez Island: main landing site (1), additional landing site (2), reserve landing site (3).

Winter Island: on the SE side of the island, directly in front of Wordie House (see maps, Figs. 1, 2). 


\section{Closed area}

To preserve the terrestrial (rich moss and lichen vegetation, initial soils, and nesting areas) and sea biodiversity, all areas not specifically designated for tourist activities are closed for them. Particular attention should be paid to the closed waters between the islands.

* These rules also apply to the Akademik Vernadsky station personnel and other members of the National Antarctic programs who visit the Argentine Islands for recreational purposes.

\section{Guided walking area}

There are two recommended tourist routes within the Argentine Islands.

On the Galindez Island-from Akademik Vernadsky station on Marina Point to the emergency base and further along old buildings (aerology hut, precipitation gauge, etc.) to the top of the ice cap called Woozle Hill (51 m).

On the Winter Island: from the Historic Site Wordie House on the SE side of the island to the top of the ice cap.

It is forbidden to deviate from the tourist route and to approach the scientific objects along it, as well as to step on rocks covered with mosses.

\section{Free-roaming area}

No free-roaming area. Due to the uneven landscape and cliffs, visitors are forbidden to roam unaccompanied by guide supervisors or to deviate from the tourist routes.

\section{Visitor code of conduct}

Behavior ashore:

- All visits are to follow the General Guidelines for Visitors to the Antarctic (Resolution 3 (2011)) and the Yachting guidelines for Antarctic cruises (Resolution 10 (2012)).

- Visits to Akademik Vernadsky station are to follow the Ukraine policy regarding visits by tourists to Akademik Vernadsky station (ATCM XXXIV IP-110 with the attachment).

- Visits to the Historic Site Base F ("Wordie House") are to follow the Visitor Guidelines for the Winter Island (Resolution 1 (2010)).

- While using tourist routes, ensure visitors are guided. Do not walk on any vegetation. Do not collect fossils, plants, mosses, shells; also, do not chip ice from the glaciers.

- Avoid disrupting penguin routes to and from the sea. Always give animals the right-of-way.

- Visitors should not touch scientific equipment, especially cameras observing the penguin colonies, since it can distort the records.

Comments:

Visits should always be kept to areas where the snow is thick enough to avoid damage to the vegetation, particularly moss and lichen, abundant across all exposed rock and boulder areas.

Small boat cruising is an appropriate alternative to landing at this site, particularly late in the season when the snow has melted, exposing more vegetation.

Cautionary notes:

Please be tolerant and don't disturb wild animals and birds approaching a closed area's border. Keep a distance of at least $10 \mathrm{~m}$ from them, especially if you meet big mammals: seals, sea elephants, and sea leopards can harm a human if scared.

Many small bays indented in the Argentine Islands coastline are convenient for yacht anchorage, especially in bad weather. However, small boat drivers should be aware of submerged rocks and foul waters between Skua and Galindez Islands. Compacted snow and ice around the coastline can be undercut by seawater, which results in dangerous overhangs. 


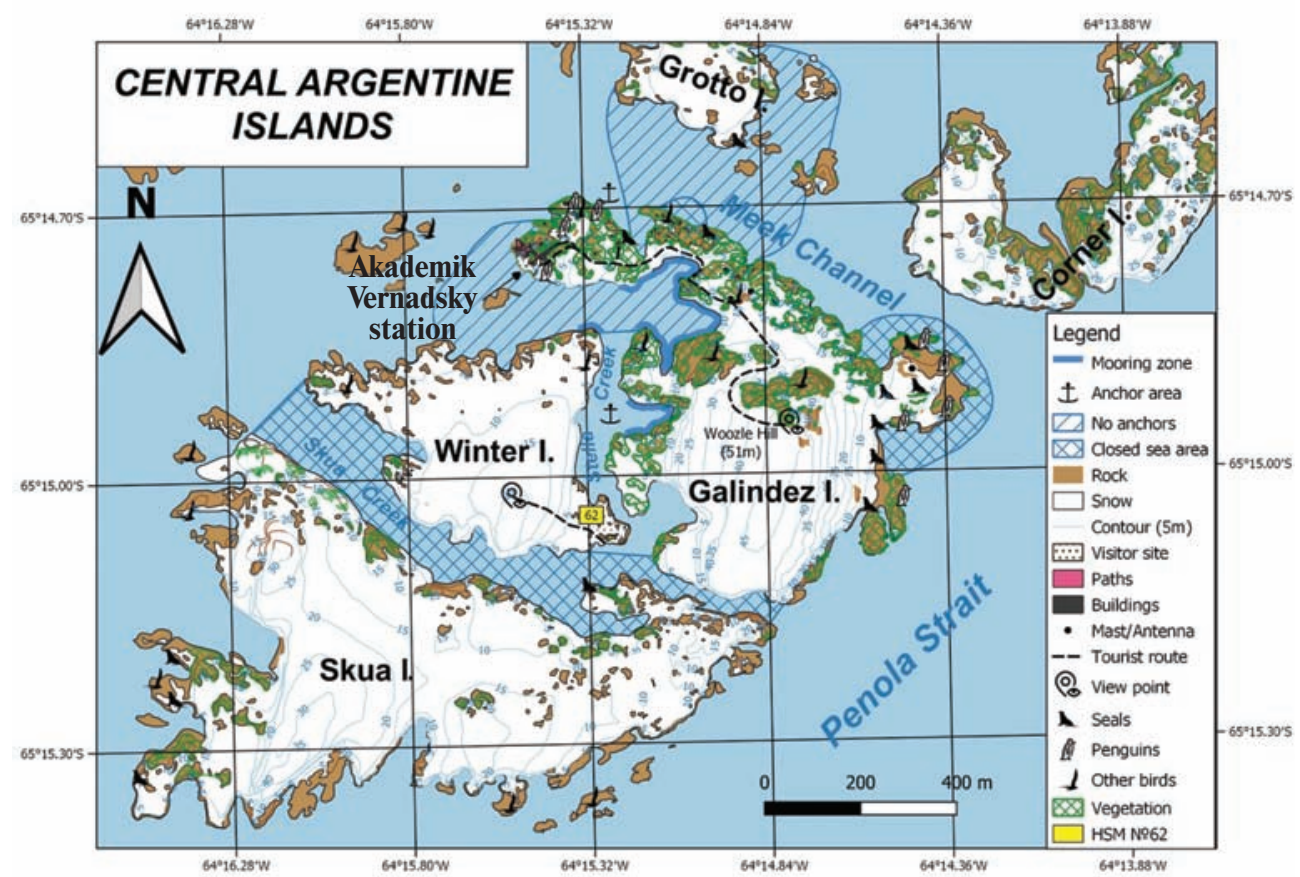

Figure 1. Map of values, buildings, and landing requirements for central Argentine Islands: Galindez Island, Winter Island, and Skua Island

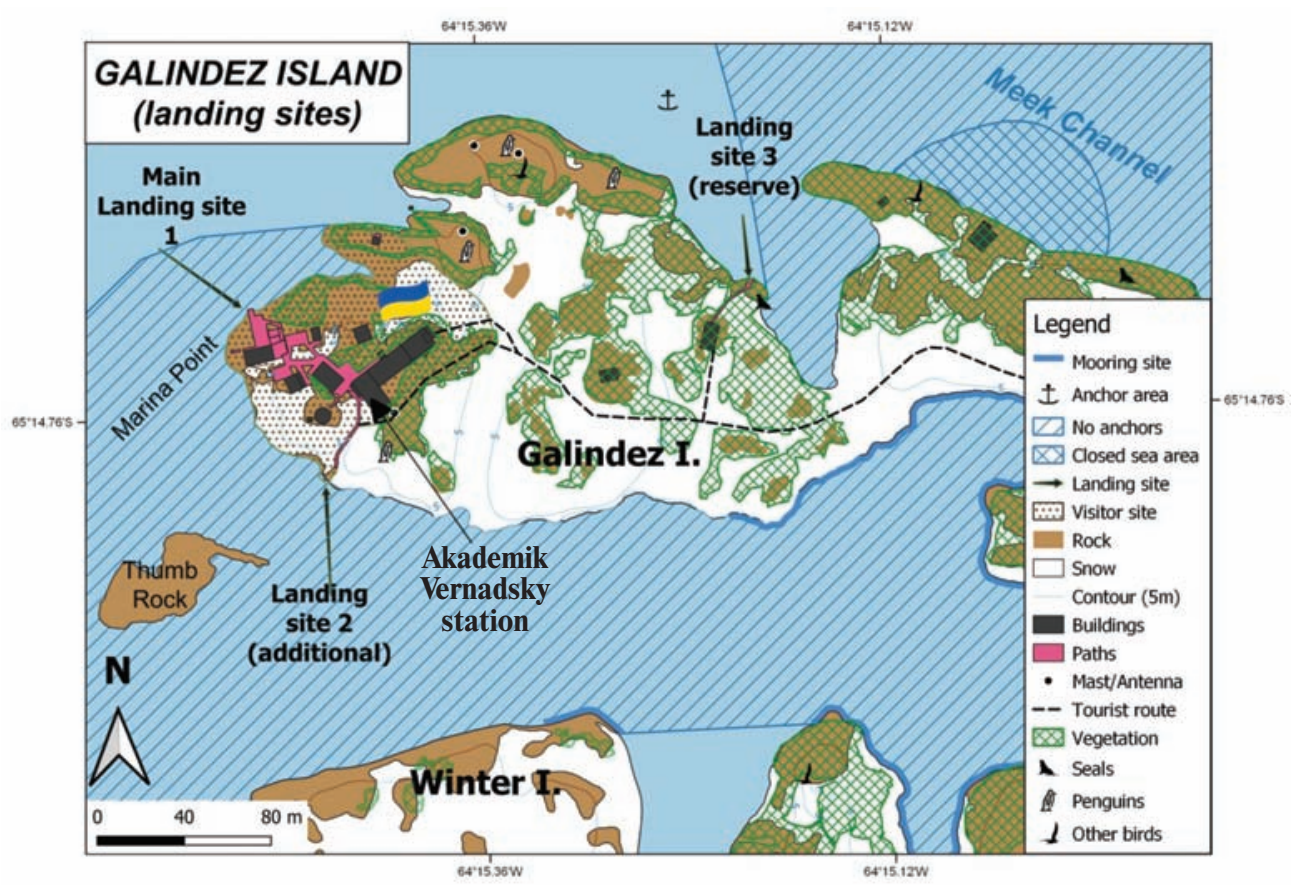

Figure 2. Map of values, buildings, and landing requirements for Marina Point, Galindez Island 